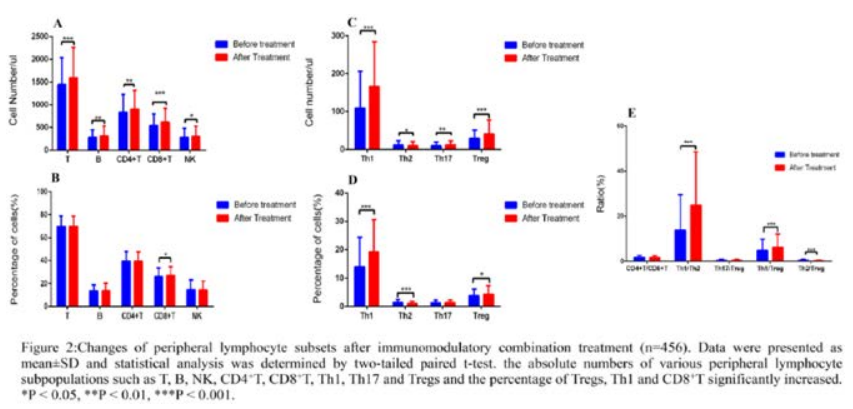

Disclosure of Interests: None declared

DOI: 10.1136/annrheumdis-2020-eular.1853

\section{SAT0358 A ROLE FOR IL-4 AND IL-13 IN MODULATING THE IL-23/LL-17 AXIS IN ENTHESITIS}

C. Bridgewood ${ }^{1}$, K. Sharif ${ }^{1}$, H. Rowe ${ }^{1}$, T. Russell ${ }^{1}$, D. Mcgonagle ${ }^{1} .{ }^{1}$ University of Leeds, Leeds Institute of Rheumatic and Musculoskeletal Medicine, Leeds, United Kingdom

Background: IL-4 and IL-13 are related Th2 cytokines, with documented roles in allergic inflammation such as atopic dermatitis (AD). Psoriatic Arthritis (PsA) is typically thought to be a result of Th1/Th17 driven response, and blockage of this pathway (IL-23, IL-17 and TNF) has proven successful. Despite this, there is a strong genetic risk association for IL-13 and PsA(1), however, the precise role of IL-13 in PsA is presently unknown. The enthesis is the region where tendons or ligaments attach to bone, and inflammation of this site (enthesitis) is thought to be the cardinal lesion of PsA, whereas as Rheumatoid Arthritis inflammation is more synovial centric. Dupilumab is a monoclonal antibody that works by blocking the common receptor chain (IL-4a) shared by both IL-13 and IL-4. Recent studies have reported that AD patients receiving dupilumab have developed clinical enthesitis(2).

Objectives: To investigate whether IL-4 and IL-13 could modulate IL-23production from entheseal myeloid cells and IL-17 production from enthseal T-cells. Methods: Healthy enthesis samples from patients undergoing surgery for non-inflammatory conditions such a lumbar decompression or scoliosis were obtained. Enthesis samples were digested and stimulated (Fig 1A) with LPS and anti-CD3 to induce IL-23 and IL-17 respectively. Samples were pre-treated with IL-4 and IL-13 to ascertain whether this modulated entheseal cytokine production.

Results: Both IL-23 and IL-17 were readily induced from enthesis samples with IL-23 coming predominantly from entheseal myeloid resident cells (Fig 1B) and IL-17A from T-cells (Fig 1C). Pre-treatment of entheseal digested material with either IL-4 or IL-13 attenuated IL-23 secretion (Fig 1D). Neither IL-4 nor IL-13 was able to significantly attenuate IL-17 secretion from enthesis T-cells, however IL-13 trended downwards and IL-4 surprisingly trended upwards (Fig 1E).

Conclusion: Our clinical and vitro data point towards a previously unknown role for IL-4 and IL-13 having a protective role in entheseal induction of IL23/17 axis cytokines. These findings point towards a novel explanation for IL-13 pathway SNPs in PsA and also a molecular explanation for why anti-IL4/13 therapy may induce entheseal pathology.

References:

[1] BOWES, J., S. EYRE, E. FLYNN, P. HO, S. SALAH, R.B. WARREN, H. MARZO-ORTEGA, L. COATES, R. MCMANUS, A.W. RYAN, D. KANE, E. KORENDOWYCH, N. MCHUGH, O. FITZGERALD, J. PACKHAM, A.W. MORGAN, C.E. GRIFFITHS, I.N. BRUCE, J. WORTHINGTON and A. BARTON.
A)

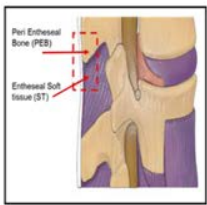

B)Enthesis Myeloid cells

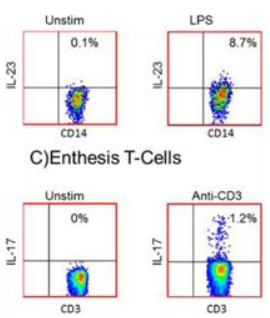

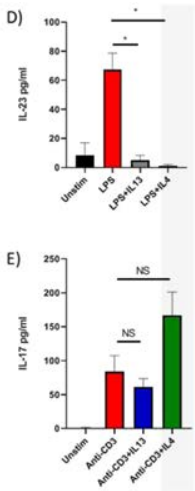

Evidence to support IL-13 as a risk locus for psoriatic arthritis but not psoriasis vulgaris. Ann Rheum Dis, 2011, 70(6), pp.1016-9.

[2] WILLSMORE, Z.N., R.T. WOOLF, C. HUGHES, B. MENON, B. KIRKHAM, C. SMITH and A. PINK. Development of inflammatory arthritis and enthesitis in patients on dupilumab: a case series. British Journal of Dermatology, 2019 181(5), pp.1068-1070.

Disclosure of Interests: Charlie Bridgewood: None declared, Kassem Sharif: None declared, Hannah Rowe Grant/research support from: Novartis UK Investigator Initiated non-clinical research funding support, Tobias Russell Grant/ research support from: Novartis UK Investigator Initiated non-clinical research funding support, Dennis McGonagle Grant/research support from: Janssen Research \& Development, LLC

DOI: 10.1136/annrheumdis-2020-eular.5533

\section{SAT0359 THE ASSOCIATION BETWEEN IMAGING SUB- PHENOTYPES OF PSORIATIC ARTHRITIS AND GENE EXPRESSION PROFILES}

L. Eder ${ }^{1}$, Q. Li ${ }^{1,2}$, S. Rahmati ${ }^{3}$, I. Eshed ${ }^{4}$, P. Rahman ${ }^{2}$, I. Jurisica ${ }^{1,3}$, V. Chandran ${ }^{1,2,3} .{ }^{1}$ University of Toronto, Toronto, Canada; ${ }^{2}$ Memorial University, St. John's, Canada; ${ }^{3}$ Krembil Research Institute, Toronto, Canada; ${ }^{4}$ Sheba Medical Center, Tel Hashomer, Israel

Background: Heterogeneity is a hallmark of psoriatic arthritis (PsA), which is reflected in diverse clinical, imaging and molecular features that may reflect disease course and response to treatment. We hypothesized that specific molecular pathways underlie the various manifestations of PsA.

Objectives: To create a model for accurate and biologically meaningful sub-phenotyping of PsA using imaging and molecular data. Specifically, we aimed to identify imaging sub-phenotypes in patients with PsA and determine their association with whole blood mRNA expression markers.

Methods: 55 patients with PsA ready to initiate treatment for active disease were prospectively recruited. An ultrasound assessment of the extent of musculoskeletal inflammation in 64 joints, 34 tendons and 16 entheses was performed. Sonographic inflammation (in greyscale and Doppler) of the following domains was graded for: a) synovitis; b) peri-tendonitis; c) tenosynovitis; and d) enthesitis. A global inflammatory score was calculated for each tissue domain. Peripheral blood was profiled with RNAseq, and gene expression data were obtained. Analyses were performed in two stages: 1) Unsupervised cluster analysis was performed using hierarchial and k-means to define imaging sub-phenotypes in PsA that reflected the predominant tissue involved; 2) Principal component analysis with ellipses was used to determine the association between imaging-defined clusters and peripheral blood gene expression profile.

Results: The patients could be divided into 3 groups based on unsupervised hierarchical and k-means clustering of images indicating the predominant involved tissue (Figure 1): 1) Enthesitis predominant ( $\mathrm{N}=13$ [24\%]); 2) Peri-tendonitis predominant $(\mathrm{N}=11[20 \%])$; 3 ); Synovitis predominant $(\mathrm{N}=31$ [56\%]). Patients in the synovitis predominant group had more nail involvement, while those in the peri-tendonitis group had the highest number of clinically active joints (Table 1). Unsupervised clustering of gene expression data identified three clusters that partially overlapped with the imaging clustering (Figure 2). Overall, 344 genes were differentially expressed $(p<0.05)$ in two of the three comparisons between the imaging clusters.

Table 1. Clinical Features by Imaging Clustering

\begin{tabular}{|c|c|c|c|}
\hline Variable & $\begin{array}{l}\text { Enthesitis } \\
\text { predominant } \\
\text { cluster } \\
(\mathrm{N}=13)\end{array}$ & $\begin{array}{l}\text { Peritendonitis predomi- } \\
\text { nant cluster } \\
(\mathrm{N}=11)\end{array}$ & $\begin{array}{l}\text { Synovitis pre- } \\
\text { dominant cluster } \\
\qquad(\mathrm{N}=31)\end{array}$ \\
\hline Age (years) & $47(14)$ & $49(16)$ & $45(20)$ \\
\hline Sex: Female & $8(61.5 \%)$ & $5(45.5 \%)$ & $15(48.4 \%)$ \\
\hline PsA duration (years) & $1.2(1.5)$ & $1.6(11.5)$ & $0.8(3.7)$ \\
\hline BMI & $29.4(6.8)$ & $25(8.1)$ & $26.1(8.4)$ \\
\hline Nail lesions & $3(23.1 \%)$ & $5(45.5 \%)$ & $17(54.8 \%)$ \\
\hline PASI & $1.2(2.7)$ & $1.2(3.2)$ & $2.8(7.8)$ \\
\hline Tender joint count & $6(9)$ & $11(5)$ & $3(6)$ \\
\hline Swollen joint count & $2(6)$ & $10(7)$ & $3(6)$ \\
\hline Dactylitis & $3(23.1 \%)$ & $4(36.4 \%)$ & $7(22.6 \%)$ \\
\hline Enthesitis count & $3(3)$ & $1(4)$ & $0(2)$ \\
\hline Enthesitis & 12 (92.3\%) & $7(63.6 \%)$ & $15(48.4 \%)$ \\
\hline hsCRP & $2.9(8.8)$ & 8.5 (21.5) & $3.6(9.4)$ \\
\hline
\end{tabular}

Median (IQ range) and frequencies (\%)

Bolded=Statistically different between the 3 groups $(p<0.05)$

Conclusion: We identified three different imaging clusters based on the predominant tissue involved in patients with active PsA. Distinct gene expression profiles may underlie these imaging clusters seen in PsA. 
Acknowledgments: The study was supported by a Discovery Grant from the National Psoriasis Foundation.

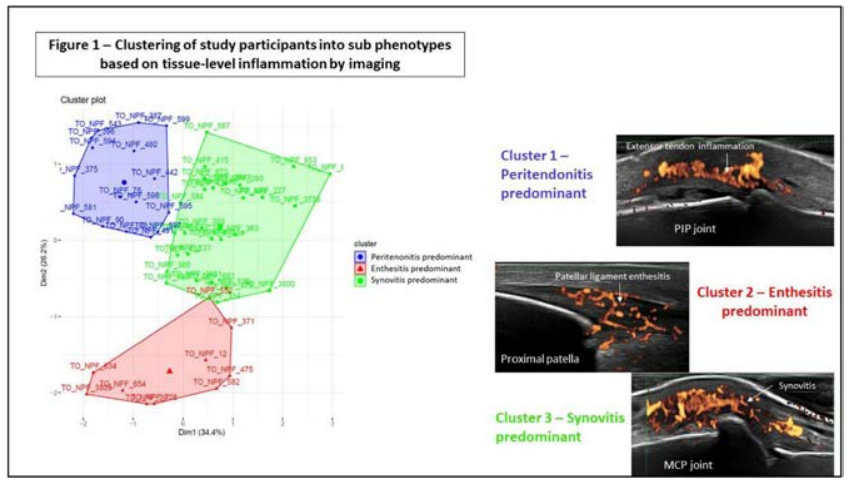

Disclosure of Interests: Lihi Eder Grant/research support from: Abbvie, Lily, Janssen, Amgen, Novartis, Consultant of: Janssen, Speakers bureau: Abbvie, Lily, Janssen, Amgen, Novartis, Quan Li: None declared, Sara Rahmati: None declared, Iris Eshed: None declared, Proton Rahman Grant/research support from: Janssen and Novartis, Consultant of: Abbott, AbbVie, Amgen, BMS, Celgene, Lilly, Janssen, Novartis, and Pfizer., Speakers bureau: Abbott, AbbVie, Amgen, BMS, Celgene, Lilly, Janssen, Novartis, Pfizer, Igor Jurisica Grant/ research support from: IBM, Vinod Chandran Grant/research support from: Abbvie, Celgene, Consultant of: Abbvie, Amgen, Bristol-Myers Squibb, Celgene, Eli Lily, Janssen, Novartis, Pfizer, UCB, Employee of: Spouse employed by Eli Lily

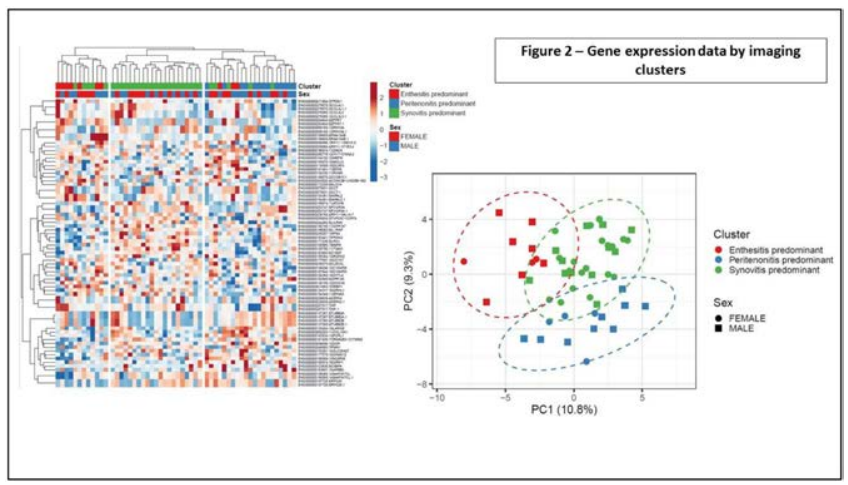

DOI: 10.1136/annrheumdis-2020-eular.1709

\section{SAT0360 \\ BACTERIAL TRANSLOCATION IN THE ADJUVANT INDUCED ARTHRITIS MODEL: PRELIMINARY STUDY AND IMPACT OF NSAIDS}

S. Hecquet ${ }^{1}$, R. Bordy ${ }^{2}$, C. Prati ${ }^{1}$, D. Wendling ${ }^{1}$, C. Demougeot ${ }^{2}$, F. Verhoeven ${ }^{1}$. ${ }^{1}$ CHRU Jean Minjoz, Rheumatology, Besançon, France; ${ }^{2}$ PEPITE EA4267, Besançon, France

Background: In patients with spondyloarthritis, the presence of intestinal inflammation and an increase in digestive permeability responsible for bacterial translocation has been described. No data are available on the effect of non-steroidal anti-inflammatory drugs (NSAIDs) on this bacterial translocation in patients with spondyloarthritis. Zonulin and lipopolysaccharide (LPS) have been described as good biomarkers of intestinal permeability and bacterial translocation, respectively. Adjuvant-induced arthritis (AIA) is a model of recent arthritis characterized by ossification and ankylosis in the post arthritis period. This model can be considered as a model of reactive arthritis in which our previous work has reported a clear efficacy of NSAIDs with differences between molecules at the structural and vascular levels.

Objectives: To test the hypothesis that there is an increase in digestive permeability and bacterial translocation in the AIA model and to show the influence of different NSAIDs on these two parameters.

Methods: Adjuvant-induced arthritis (AIA) was induced in 6-week-old male Lewis rats by an injection at the base of the tail of Mycobacterium butyricum. A group of non-AIA (control) rats received saline. At the first signs of arthritis, the AIA-rats were evaluated (arthritis score 0-6) and treated daily intraperitoneally with naproxen $(10 \mathrm{mg} / \mathrm{kg} /$ day $)$, diclofenac $(5 \mathrm{mg} / \mathrm{kg}$ twice daily), celecoxib (3 mg/kg/day) or saline solution (AIA-vehicle group). After 21 days of treatment, the rats were sacrificed and serum levels of zonulin and LPS were

evaluated by ELISA and liquid chromatography-mass spectrometry, respectively. Circulating levels of TNF- $\alpha$ and IL1- $\beta$ and paw radiographic score were measured.

Results: Compared to the control group, there was a significant increase in zonulin concentration $(p<0.001)$ in the AIA group. There was no significant difference in the concentration of LPS between the two groups. The levels of zonulin were correlated with the TNF- $a$ levels $(R=-0.42 ; p=0.032)$ and the arthritis score $(R=0.45 ; p=0.013)$ but not with the level of IL1- $\beta(R=; p-0.018 ; p=0.39)$. Treatment with NSAIDs significantly and equivalently decreased the arthritis score in each group. Compared to the vehicle group, treatment with naproxen significantly decreased the radiographic score $(p<0.001)$, TNF- $a$, IL1- $\beta(p<0.01)$, zonulin $(p<0.001)$ and LPS $(p<0.05)$. Celecoxib decreased radiographic score $(p<0.001)$, IL1- $\beta$ ( $p<0.01)$, TNF- $a(p<0.01)$ but increased zonulin levels $(p<$ 0.05 ) without effect on LPS. Diclofenac also decreased radiographic score ( $p<$ $0.001)$, TNF- $\alpha(p<0.01)$, and IL1- $\beta(p<0.01)$ but increased both zonulin ( $p<$ $0.01)$ and LPS $(p<0.001)$.

Conclusion: We have demonstrated an increase in serum zonulin levels in the AIA model and a beneficial effect of naproxen on intestinal permeability and bacterial translocation in contrast to celecoxib and diclofenac. Moreover, the plasmatic zonulin levels were correlated with TNF-a supporting a pivotal role of TNF-a on the tight junctions in this model.

Disclosure of Interests: Sophie Hecquet: None declared, Romain Bordy: None declared, Clément Prati: None declared, Daniel Wendling: None declared, Céline Demougeot Grant/research support from: With an institutional support from Pfizer., Frank Verhoeven: None declared DOI: 10.1136/annrheumdis-2020-eular.3508

\section{SAT0361 HEALTHY HUMAN SPINAL PROCESSES PERI- ENTHESEAL T-CELLS EXHIBIT A TR1 RATHER THAN A FOXP3 REGULATORY PHENOTYPE}

H. Rowe ${ }^{1}$, A. Watad ${ }^{1}$, T. Russell ${ }^{1}$, K. Sharif ${ }^{1}$, D. Newton ${ }^{1}$, M. Wittmann ${ }^{1}$, Q. Zhou ${ }^{1}$, A. Khan ${ }^{2}$, P. Loughenbury ${ }^{2}$, R. Dunsmuir ${ }^{2}$, A. S. Rao ${ }^{2}$, P. Millner ${ }^{2}$, T. Kenna ${ }^{3}$, M. Brown ${ }^{4}$, C. Bridgewood ${ }^{1}$, D. Mcgonagle ${ }^{1} .{ }^{1}$ University of Leeds, Leeds Institute of Rheumatic and Musculoskeletal Medicine, Leeds, United Kingdom; ${ }^{2}$ The Leeds Teaching Hospital, NHS Trust, Leeds, United Kingdom; ${ }^{3}$ Institute of Health and Biomedical Innovation, Queensland University of Technology, Woolloongabba, Australia; ${ }^{4}$ King's College London, London, United Kingdom

Background: We have previously reported that the normal spinal enthesis has populations of conventional T-cells including CD4+ \& CD8+ T-cells that could be induced to produce IL-17A and TNF following anti-CD3/CD28 stimulation. The biology of such cells in health including their normal function and antigen reactivity is completely unknown. The purpose of this work was to define the phenotype, functionality and TCR reactivity of such T-cells in health.

Figure 1. Transcriptional profiling of T-cells

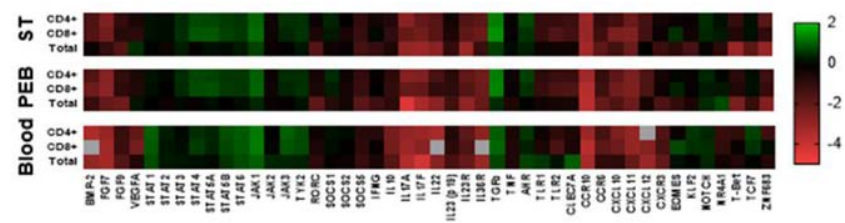

Figure 2. TGF $\beta$ from secretion enthesis T-cells

Stained

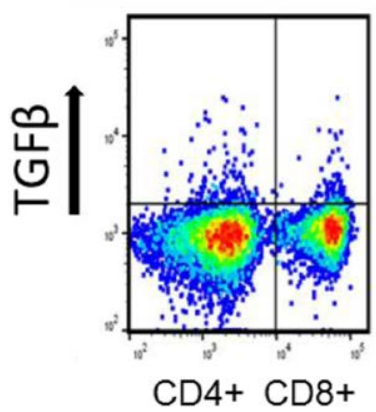

FMO

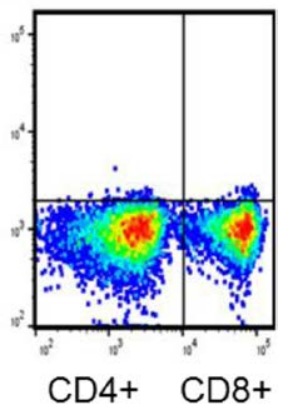

